\title{
Clinical biomechanic correlates for cervical function: Part II. A myoelectric study
}

\author{
JOSEPH VORRO, PH.D. \\ WILLIAM L. JOHNSTON, D.O., FAAO \\ East Lansing, Michigan
}

\begin{abstract}
Part I of this study compared cervical motion ranges for two groups of human subjects classified as symmetric or asymmetric on the basis of a single clinical test for cervical sidebending. Data from the asymmetric group revealed limited mobility in all primary rotations and in secondary deviations. Part II reports on the concurrent, bilateral measurement of electromyographic activity for 12 selected muscle sites during the movements executed. Data revealed that muscles in the asymmetric group were slower to initiate action and were reduced in time and strength of contraction. Because muscles provide the motive forces for the reduction in range previously reported, these myoelectric data expand understanding of the disturbance in physiologic function that is indicated when a clinical test for response to motion in a spinal region is positive for asymmetry.
\end{abstract}

The present report is a continuation of a study of human subjects that was designed to examine biomechanical patterns of movement in the cervical spinal region. Specifically, we examined kinematic and electromyographic (EMG) responses for head and neck motions in two sample populations: (1) subjects demonstrating functional symmetry in their equivalent responses to opposing directions of a major cervical motion test; and (2) subjects diag- nosed as demonstrating asymmetric responses to that motion.

In our initial paper on kinematic responses, ${ }^{1}$ we described significant decreases in total range of cervical motion and reduced secondary movements for subjects in the asymmetric group. We have now examined our subject groups for similarities and differences in the muscular activity that provided the motive forces for these kinematic observations.

\section{Methods of procedure \\ Selection of subjects}

The myoelectric data reported here were gathered concurrently with the previously reported kinematic data. ${ }^{1}$ The sample population consisted of 17 men selected from volunteers in the Michigan State University community. ${ }^{*}$ The subjects were selected by complete agreement of three independent, trained examiners regarding the presence of palpable symmetry or right or left asymmetry in response to a passive motion test for cervical lateral flexion (sidebending). Six subjects who were diagnosed as having symmetric responses to this test constituted the symmetric (control) group. The asymmetric (experimental) group consisted of 11 subjects, 6 of whom were diagnosed as showing right cervical asymmetry (more limited in response to cervical sidebending right than left), and 5 of whom were diagnosed as showing left cervical asymmetry. All subjects were right-handed, with the exception of a subject with left cervical asymmetry, who was left-hand dominant. Subjects were

\footnotetext{
* Kinematic data were available for only 16 of the original 17 subjects because of instrument failure. ${ }^{1}$
} 
not selected on the basis of symptoms, nor were they currently experiencing pain upon cervical motion.

\section{Electromyographic procedures}

Three specific muscle sites and three spinal sites on the paravertebral musculature were each monitored bilaterally. Although the composite contribution of these muscles to cervical motions was yet unclear, each site provided superficial landmarks that facilitated uniform placement of surface electrodes to sample the muscular performance. Cutaneous stimulation was used to determine the motor points of two muscles, the sternocleidomastoid and cervical portion of the trapezius muscle. The splenius capitis muscle, the motor point of which we could not determine, was located by palpation in the superior portion of the posterior triangle of the neck, where it could be found close to the surface of the skin, and between the sternocleidomastoid and trapezius muscles. Palpation of spinous and transverse processes of the cervical vertebrae served to identify two of the spinal sites, cervical level 3 (C3) and cervical level 6 (C6) for subsequent electrode placement. Finally, a sixth electrode placement was made in the superior-posterior thoracic region (T1-2) to sample paravertebral muscle activity just inferior to the base of the cervical region.

Once the individual locations were identified, they were marked, cleansed, and prepared for electrode application. Resistance measures of each site were made with a volt-ohm meter, and values of less than 3,000 ohms were achieved. Beckman miniature bipolar surface electrodes were used. In the cases where motor points were identified (trapezius and sternocleidomastoid sites), the electrodes were placed side by side directly over the motor points. In the case of the splenius capitis muscle, the electrodes were placed on the midpoint of the area palpated for that muscle. Lastly, electrodes were placed bilaterally $1 \mathrm{~cm}$. to the right and to the left of the midline at each of the three spinal levels of interest. An ear-clip electrode served as the ground.

Myoelectric activity was monitored during six primary rotation movements of the head and neck. These were forward flexion and backward flexion (hyperextension), sidebending right and left (flexion right and left), and axial rotation right and left.

The myopotentials were processed and recorded by a six-channel Grass Model 7 Polygraph. The polygraph was equipped with six Grass Model 7P3 preamplifiers with response characteristics of $6 \mathrm{DB}$ cutoff points at 10 and $75 \mathrm{~Hz}$., with a $6 \mathrm{DB}$ per octave roll-off at the high and low frequencies. In addition, the polygraph utilized six Model 7DA driver ampli- fiers, with a band width of 10 to $75 \mathrm{~Hz}$. The preamplifier calibration selectors were set at $200 \mu \mathrm{V}$. All activity was recorded in the "raw" mode on curvilinear chart paper.

The kinematic observations (video) and the EMG data were synchronized through the use of a specially constructed timer. ${ }^{2}$ The event marker of the polygraph was controlled by the timer so that a mark was placed on the EMG record every $0.1 \mathrm{sec}-$ ond. The paper speed of the EMG was $5 \mathrm{~mm}$./second; thus, each millimeter on the paper represented 0.2 second. Interfaced with the electronic timer was a TEL Video Counted Timer, which superimposed the elapsed time of a movement event (in 0.1 second intervals) on the video signal. The electronic timer was equipped with a reset switch; when depressed, it stopped both the event marker on the EMG record and the video timer for the kinematic observations. Release of the switch actuated the marker and timer so that they started simultaneously at zero.

Once the subjects were ready to perform a movement, the polygraph and the video recorder were started. Following this, the event marker and the video timer were zeroed. A short verbal countdown was given to the subjects, and the event pen and video timer were actuated. The subjects were permitted to perform the specifically required movement any time subsequent to the actuation of the timing equipment.

A procedure was needed that allowed simultaneous comparisons between the electrical output from the muscles and the coincident kinematic events. In addition, a reference was needed to examine temporal phenomena within the EMG data. To address these issues, individual frames of the recorded images were played back and analyzed on a video monitor. Monitoring of the head movement was done, beginning with the frame that displayed the first visible sign of movement (displacement of the tips of the orthogonal target), ${ }^{\dagger}$ and the elapsed time to that point was recorded. ${ }^{1}$ The beginning time of the movement was then transposed from the video record to the polygraph chart, with fulfillment of the requirements for data reduction.

\section{Data treatment and statistical procedure}

The EMG data were reduced directly from the chart paper. They yielded three myotemporal dependent variables and one myoelectric dependent variable for each of the six muscles (Fig. 1). ${ }^{\ddagger}$ For the

\footnotetext{
† Head orientation was monitored with an orthogonal targeting system, which was attached to a mouthpiece. ${ }^{3}$

‡ During data accumulation and data reduction phases, EMG measurements were examined without knowledge of the diagnostic grouping of the subjects.
} 
determination of the myotemporal variables, the total amount of time (in seconds) the head was involved in each of the actual motions was calculated from the video records. This included the time taken from the onset of motion to the end point of range, and the time for the return excursion back to an end point of movement.

The three time-dependent variables were as follows: (1) Time to beginning (TB) - the time elapsed prior to the beginning of electrical activity, measured in seconds and expressed in terms of the percentage of total head movement time, with the criterion for muscular activity a polygraph pen displacement of greater than $1 \mathrm{~mm}$.; (2) time to peak (TP) - time elapsed between the beginning of electrical activity and peak activity, measured in seconds and expressed as a percentage of total head movement time; and (3) total time (TT) - time elapsed between the beginning of electrical activity and the end of electrical activity, measured in seconds and expressed as a percentage of total head movement time.

The fourth dependent variable was myoelectric and consisted of a quantitative measure of the relative amount of total electrical activity for each muscle (total activity-TA). For this procedure, the EMG records were graded (peak-to-peak pen deflection) on a basis of the following: no activity $=0$; minimal (less than $2.5 \mathrm{~mm}$. pen deflection $)=0.25$; very slight $(2.5$ to $5 \mathrm{~mm}$. pen deflection $)=0.50$; slight $(5-15 \mathrm{~mm}$. deflection $)=1.0 ;$ moderate $(15-20$ $\mathrm{mm}$. deflection $)=2.0$; marked $(20-35 \mathrm{~mm}$. deflection $)=3.0$; and very marked $(35 \mathrm{~mm}$. deflection or greater) $=4.0 .4$

The six primary rotation movements were carried out a total of four times, twice in an active and twice in a passive phase, so as to yield 24 observations for each subject. The kinematic data ${ }^{1}$ had revealed no significant differences between active and passive movements. In the current part of the study, the numbers were treated as one data set, and the analysis was made between individual paired symmetric and asymmetric observations.

Because only a limited number of polygraph channels were available for recording the EMG activity, the entire set of 24 observations was repeated a second time; that is, they were recorded once (initially) from the right side of the body and once (subsequently) from the left side, for a total of 48 observations per subject. For each of these observations, there were the associated 4 dependent variables recorded from the six different muscles.

The final variable was the diagnostic category of the subjects. Six subjects were judged symmetric and 11 asymmetric; these yielded 288 observations under symmetric and 528 observations under

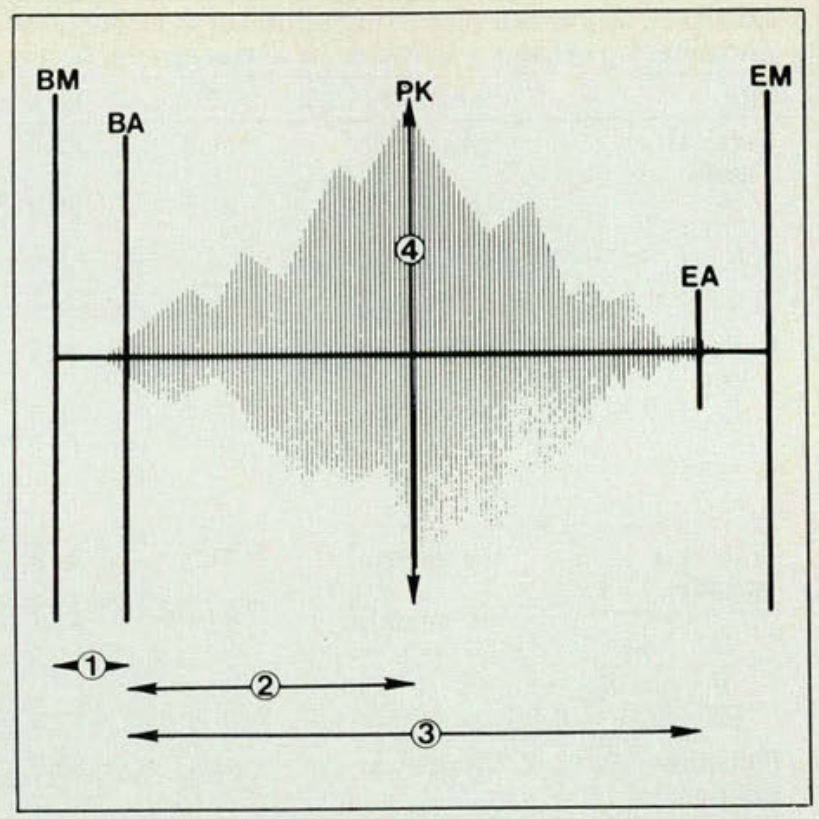

Fig. 1. An example of the EMG signal and the measurement points for the four dependent variables-time to beginning, time to peak, total time, and total activity.

asymmetric conditions.

The multivariate analysis of variance (MANOVA) procedure was used to analyze variations in the data. Factors in the analysis included symmetric and asymmetric subjects. The dependent (criterion) measures of EMG activity included the three myotemporal and one myoelectric variables. A profile analysis was used to examine individual difference in the four measures. ${ }^{5}$ Three a priori contrasts, which were intended to evaluate movements of the head and neck, were included in the design: (1) forward flexion versus hyperextension; (2) flexion right versus flexion left; and (3) axial rotation right versus rotation left.

\section{Results}

With the significant loss of total motion range and reduced secondary movement observed in the asymmetric subjects when compared with symmetric subjects, ${ }^{1}$ it would seem reasonable to assume that numerous differences would have had to occur in the musculature that provided the motive forces for these movements. We looked at differences in all four dependent variables (TB, TP, TT, TA) as a basis for comparing the EMG activity in the two groups of subjects.

\section{Time to the beginning of activity (TB)}

Descriptive observations. Table 1 presents the muscle $\times$ symmetry $\times$ side data for the mean time taken for each muscle to begin electrical activity in relation to the beginning of head motion. For each of the electrode sites in Table 1, muscles of sym- 


\begin{tabular}{|c|c|c|c|c|c|c|c|c|}
\hline Site & Symmetry & $\overline{\mathrm{X}}$ & S.D. & No. & Side & $\overline{\mathrm{X}}$ & S.D. & No. \\
\hline $\begin{array}{c}\text { Cervical } \\
\text { level } \\
3\end{array}$ & $\begin{array}{l}\text { Symmetric } \\
\text { Asymmetric }\end{array}$ & 60.8 & 39.9 & $\begin{array}{l}160 \\
404\end{array}$ & $\begin{array}{l}\text { Right } \\
\text { Left } \\
\text { Right } \\
\text { Left } \\
\text { Right side } \overline{\mathrm{X}} \\
\text { Left side } \overline{\mathrm{X}}\end{array}$ & $\begin{array}{l}50.8 \\
49.8 \\
57.9 \\
63.2 \\
55.3 \\
60.4\end{array}$ & $\begin{array}{l}39.2 \\
40.6 \\
39.2 \\
40.4 \\
39.3 \\
40.7\end{array}$ & $\begin{array}{r}103 \\
57 \\
182 \\
222 \\
285 \\
279\end{array}$ \\
\hline $\begin{array}{c}\text { Cervical } \\
\text { level } \\
6\end{array}$ & $\begin{array}{l}\text { Symmetric } \\
\text { Asymmetric }\end{array}$ & $\begin{array}{l}57.2 \\
69.7\end{array}$ & $\begin{array}{l}39.4 \\
39.0\end{array}$ & $\begin{array}{l}160 \\
404\end{array}$ & $\begin{array}{l}\text { Right } \\
\text { Left } \\
\text { Right } \\
\text { Left } \\
\text { Right side } \bar{X} \\
\text { Left side } \bar{X}\end{array}$ & $\begin{array}{l}58.0 \\
55.9 \\
66.8 \\
72.1 \\
63.6 \\
68.7\end{array}$ & $\begin{array}{l}40.3 \\
38.0 \\
40.2 \\
38.0 \\
40.4 \\
38.5\end{array}$ & $\begin{array}{r}103 \\
57 \\
182 \\
222 \\
285 \\
279\end{array}$ \\
\hline $\begin{array}{l}\text { Trapezius } \\
\text { muscle }\end{array}$ & $\begin{array}{l}\text { Symmetric } \\
\text { Asymmetric }\end{array}$ & $\begin{array}{l}77.9 \\
80.1\end{array}$ & $\begin{array}{l}34.9 \\
34.7\end{array}$ & $\begin{array}{l}160 \\
404\end{array}$ & $\begin{array}{l}\text { Right } \\
\text { Left } \\
\text { Right } \\
\text { Left } \\
\text { Right side } \bar{X} \\
\text { Left side } \bar{X}\end{array}$ & $\begin{array}{l}75.5 \\
82.4 \\
75.7 \\
83.6 \\
75.6 \\
83.4\end{array}$ & $\begin{array}{l}37.1 \\
30.4 \\
37.5 \\
31.9 \\
37.3 \\
31.6\end{array}$ & $\begin{array}{r}103 \\
57 \\
182 \\
222 \\
285 \\
279\end{array}$ \\
\hline $\begin{array}{l}\text { Splenius } \\
\text { capitis } \\
\text { muscle }\end{array}$ & $\begin{array}{l}\text { Symmetric } \\
\text { Asymmetric }\end{array}$ & $\begin{array}{l}41.4 \\
53.8\end{array}$ & $\begin{array}{l}38.9 \\
42.8\end{array}$ & $\begin{array}{l}160 \\
404\end{array}$ & $\begin{array}{l}\text { Right } \\
\text { Left } \\
\text { Right } \\
\text { Left } \\
\text { Right side } \bar{X} \\
\text { Left side } \bar{X}\end{array}$ & $\begin{array}{l}39.2 \\
45.4 \\
51.2 \\
56.0 \\
46.8 \\
53.8\end{array}$ & $\begin{array}{l}38.3 \\
40.1 \\
41.9 \\
43.4 \\
41.0 \\
42.9\end{array}$ & $\begin{array}{r}103 \\
57 \\
182 \\
222 \\
285 \\
279\end{array}$ \\
\hline $\begin{array}{l}\text { Sternocleido- } \\
\text { mastoid } \\
\text { muscle }\end{array}$ & $\begin{array}{l}\text { Symmetric } \\
\text { Asymmetric }\end{array}$ & $\begin{array}{l}39.0 \\
41.9\end{array}$ & $\begin{array}{l}37.2 \\
40.5\end{array}$ & $\begin{array}{l}160 \\
404\end{array}$ & $\begin{array}{l}\text { Right } \\
\text { Left } \\
\text { Right } \\
\text { Left } \\
\text { Right side } \bar{X} \\
\text { Left side } \bar{X}\end{array}$ & $\begin{array}{l}39.1 \\
38.8 \\
40.9 \\
42.8 \\
40.3 \\
42.0\end{array}$ & $\begin{array}{l}37.0 \\
38.0 \\
39.9 \\
41.1 \\
38.8 \\
40.5\end{array}$ & $\begin{array}{r}103 \\
57 \\
182 \\
222 \\
285 \\
279\end{array}$ \\
\hline $\begin{array}{l}\text { Upper } \\
\text { thoracic } \\
\text { level }\end{array}$ & $\begin{array}{l}\text { Symmetric } \\
\text { Asymmetric }\end{array}$ & $\begin{array}{l}62.4 \\
79.5\end{array}$ & 41.5 & $\begin{array}{l}160 \\
404\end{array}$ & $\begin{array}{l}\text { Right } \\
\text { Left } \\
\text { Right } \\
\text { Left } \\
\text { Right side } \bar{X} \\
\text { Left side } \bar{X}\end{array}$ & $\begin{array}{l}68.6 \\
51.2 \\
76.4 \\
81.9 \\
73.6 \\
75.7\end{array}$ & $\begin{array}{l}40.6 \\
41.2 \\
38.1 \\
34.2 \\
39.1 \\
37.7\end{array}$ & $\begin{array}{r}103 \\
57 \\
182 \\
222 \\
285 \\
279\end{array}$ \\
\hline
\end{tabular}

metric subjects began their activity before their counterparts in asymmetric subjects. Additionally, the sequence of contraction, that is, the relative point in time when each electrode site (muscle) becomes active, was identical for the two groups. From the earliest responding site/muscle to the latest, the sequence followed this pattern: sternocleidomastoid muscle, splenius capitis muscle, C3, C6, upper thoracic level, and the trapezius muscle. Muscles on the right side of the subjects initiated their activity earlier than muscles on the left. Further analysis showed that right-side muscles of symmetric subjects initiated activity earlier than right-side muscles of asymmetric subjects. Similarly, the left-side muscles of symmetric subjects initiated activity earlier than left-side muscles of asymmetric subjects (Table 1).

A summary of the muscle $\times$ motion interactions is presented in Table 2. A comparison of the overall means for the six head motions showed that muscle activity was consistently initiated earliest for rotation motions (Table 2). This order was consistent for both groups. No other patterns were obvious for the TB variable.

Statistical evaluation. A profile analysis was used to examine relationships among subject groups (symmetry), head motion, muscles, and side of recording for the dependent measure TB, and Table 1 summarizes these means. When all movements were considered and analyzed for this variable (Table 3), a significant interaction between symmetry and side resulted $(p=<.03)$. This indicated that in regard to the pattern of muscular activity at each of the six sites, symmetric subjects differed from asymmetric subjects when right- and left-side measures were considered. That is, for TB, the profile describing the symmetric group's muscular be- 
TABLE 2. SUMMARY OF TIME TO BEGINNING OF ELECTRICAL ACTIVITY AT SIX MUSCLE SITES ACCORDING TO MOTION. VALUES ARE EXPRESSED AS A PERCENTAGE OF TOTAL HEAD MOVEMENT TIME.

\begin{tabular}{|c|c|c|c|c|c|c|c|}
\hline \multirow[b]{2}{*}{ Site } & \multirow[b]{2}{*}{ Motion } & \multicolumn{3}{|c|}{ Symmetric } & \multicolumn{3}{|c|}{ Asymmetric } \\
\hline & & $\overline{\mathrm{X}}$ & S.D. & No.! & $\int \bar{x}$ & S.D. & No! \\
\hline $\begin{array}{c}\text { Cervical } \\
\text { level } \\
3\end{array}$ & $\begin{array}{l}\text { FF } \\
\text { HYP } \\
\text { FR } \\
\text { FL } \\
\text { RR } \\
\text { RL }\end{array}$ & $\begin{array}{l}60.1 \\
66.6 \\
64.9 \\
73.5 \\
13.2 \\
16.9\end{array}$ & $\begin{array}{r}33.9 \\
41.7 \\
39.1 \\
36.9 \\
9.0 \\
9.2\end{array}$ & $\begin{array}{l}27 \\
24 \\
30 \\
29 \\
24 \\
26\end{array}$ & $\begin{array}{l}70.5 \\
71.8 \\
72.7 \\
81.7 \\
33.4 \\
37.6 \\
\end{array}$ & $\begin{array}{l}26.4 \\
37.6 \\
38.4 \\
31.5 \\
36.5 \\
39.6\end{array}$ & $\begin{array}{l}65 \\
67 \\
65 \\
67 \\
70 \\
70\end{array}$ \\
\hline $\begin{array}{c}\text { Cervical } \\
\text { level } \\
6\end{array}$ & $\begin{array}{l}\text { FF } \\
\text { HYP } \\
\text { FR } \\
\text { FL } \\
\text { RR } \\
\text { RL }\end{array}$ & $\begin{array}{l}65.0 \\
81.8 \\
65.7 \\
82.4 \\
15.8 \\
26.8\end{array}$ & $\begin{array}{r}35.4 \\
32.4 \\
35.7 \\
32.3 \\
9.4 \\
28.1\end{array}$ & $\begin{array}{l}27 \\
24 \\
30 \\
29 \\
24 \\
26\end{array}$ & $\begin{array}{l}81.1 \\
89.3 \\
81.5 \\
79.3 \\
44.3 \\
45.6\end{array}$ & $\begin{array}{l}27.1 \\
26.0 \\
33.2 \\
34.8 \\
41.1 \\
41.7\end{array}$ & $\begin{array}{l}65 \\
67 \\
65 \\
67 \\
70 \\
70\end{array}$ \\
\hline $\begin{array}{l}\text { Trapezius } \\
\text { muscle }\end{array}$ & $\begin{array}{l}\text { FF } \\
\text { HYP } \\
\text { FR } \\
\text { FL } \\
\text { RR } \\
\text { RL }\end{array}$ & $\begin{array}{r}96.7 \\
100.0 \\
83.8 \\
87.3 \\
42.3 \\
53.7\end{array}$ & $\begin{array}{r}17.4 \\
0.0 \\
30.9 \\
28.6 \\
31.0 \\
41.5\end{array}$ & $\begin{array}{l}27 \\
24 \\
30 \\
29 \\
24 \\
26\end{array}$ & $\begin{array}{l}98.2 \\
91.3 \\
85.2 \\
91.5 \\
57.7 \\
59.1\end{array}$ & $\begin{array}{l}10.0 \\
23.7 \\
31.5 \\
23.4 \\
41.3 \\
41.5\end{array}$ & $\begin{array}{l}65 \\
67 \\
65 \\
67 \\
70 \\
70\end{array}$ \\
\hline $\begin{array}{l}\text { Splenius } \\
\text { capitis } \\
\text { muscle }\end{array}$ & $\begin{array}{l}\text { FF } \\
\text { HYP } \\
\text { FR } \\
\text { FL } \\
\text { RR } \\
\text { RL }\end{array}$ & $\begin{array}{r}51.4 \\
66.6 \\
49.9 \\
54.3 \\
5.8 \\
16.4\end{array}$ & $\begin{array}{r}27.7 \\
41.0 \\
39.6 \\
41.3 \\
7.5 \\
25.6\end{array}$ & $\begin{array}{l}27 \\
24 \\
30 \\
29 \\
24 \\
26\end{array}$ & $\begin{array}{l}71.4 \\
58.6 \\
62.3 \\
76.8 \\
28.4 \\
28.5\end{array}$ & $\begin{array}{l}31.2 \\
42.4 \\
42.3 \\
38.7 \\
37.6 \\
36.8\end{array}$ & $\begin{array}{l}65 \\
67 \\
65 \\
67 \\
70 \\
70\end{array}$ \\
\hline $\begin{array}{l}\text { Sternocleido- } \\
\text { mastoid } \\
\text { muscle }\end{array}$ & $\begin{array}{l}\text { FF } \\
\text { HYP } \\
\text { FR } \\
\text { FL } \\
\text { RR } \\
\text { RL }\end{array}$ & $\begin{array}{r}65.6 \\
57.7 \\
34.8 \\
44.1 \\
21.4 \\
9.5\end{array}$ & $\begin{array}{l}40.4 \\
37.1 \\
33.7 \\
31.8 \\
26.3 \\
20.5\end{array}$ & $\begin{array}{l}27 \\
24 \\
30 \\
29 \\
24 \\
26\end{array}$ & $\begin{array}{l}63.8 \\
39.8 \\
54.8 \\
43.1 \\
21.2 \\
31.3\end{array}$ & $\begin{array}{l}39.4 \\
36.3 \\
43.4 \\
38.4 \\
34.1 \\
37.5\end{array}$ & $\begin{array}{l}65 \\
67 \\
65 \\
67 \\
70 \\
70\end{array}$ \\
\hline $\begin{array}{l}\text { Upper } \\
\text { thoracic } \\
\text { level }\end{array}$ & $\begin{array}{l}\text { FF } \\
\text { HYP } \\
\text { FR } \\
\text { FL } \\
\text { RR } \\
\text { RL }\end{array}$ & $\begin{array}{l}69.1 \\
80.6 \\
72.2 \\
72.7 \\
31.4 \\
44.7\end{array}$ & $\begin{array}{l}41.5 \\
34.6 \\
37.4 \\
38.8 \\
36.2 \\
41.3\end{array}$ & $\begin{array}{l}27 \\
24 \\
30 \\
29 \\
24 \\
26\end{array}$ & $\begin{array}{l}91.2 \\
95.9 \\
87.2 \\
86.6 \\
63.6 \\
54.7\end{array}$ & $\begin{array}{l}22.0 \\
19.8 \\
30.4 \\
30.7 \\
42.9 \\
42.4\end{array}$ & $\begin{array}{l}65 \\
67 \\
65 \\
67 \\
70 \\
70\end{array}$ \\
\hline
\end{tabular}

havior (for respective right and left sides of the body) was not parallel with (was significantly different from) the profile describing asymmetric group muscular behavior. This interaction indicated that both symmetry and side contributed to the differences found in the patterns of muscular activity.

Of particular importance to this study were the interactions of symmetry $\times$ motion. For this contrast, collapsing across sides, significant differences were found between the symmetric and asymmetric groups when comparing relations of lateral flexions (right with left) $(p=<.01)$ and of axial rotations (right with left) $(p=<.02)$ (Table 3 ). That is, the time to beginning of motion was conditioned upon whether the subjects were symmetric or asymmetric, how they flexed (to the right or left), and how they rotated (to the right or left).
Finally, collapsing across movements and sides, an overall main effect for symmetry was observed $(p=<.00003$ ) (Table 3). This indicates that when all electrode sites were considered, symmetric and asymmetric subjects differed significantly in the time to beginning of motion (Fig. 2). This difference can be interpreted not only in relation to the interactions of symmetry $\times$ side, but those of symmetry $\times$ motion. The profiles for each subject group, then, were significantly different for this TB variable. This difference depended upon the side of the body from which the recordings were made and, in addition, concerned the direction in which subjects flexed (to the right or left) and rotated (to the right or left).

Time to peak electrical output (TP)

Descriptive observations. Table 4 presents the 
muscle $\times$ symmetry $\times$ side data for the dependent variable $\mathrm{TP}$, describing the interval between the onset of electrical activity and the achievement of peak electrical output. Muscles of the symmetric group of subjects reached peak output before those of their asymmetric counterparts. The sequence of achieving peak output was identical in both groups. In order of decreasing speed, the sequence of muscle/site was again sternocleidomastoid, splenius capitis, C3, C6, upper thoracic level, and trapezius. From Table 4 it can be seen that muscles on the right side of the body, in general, reached peak output earlier than those on the left. Additionally, right-side muscles for the symmetric group reached peak output before right-side muscles of the asym-

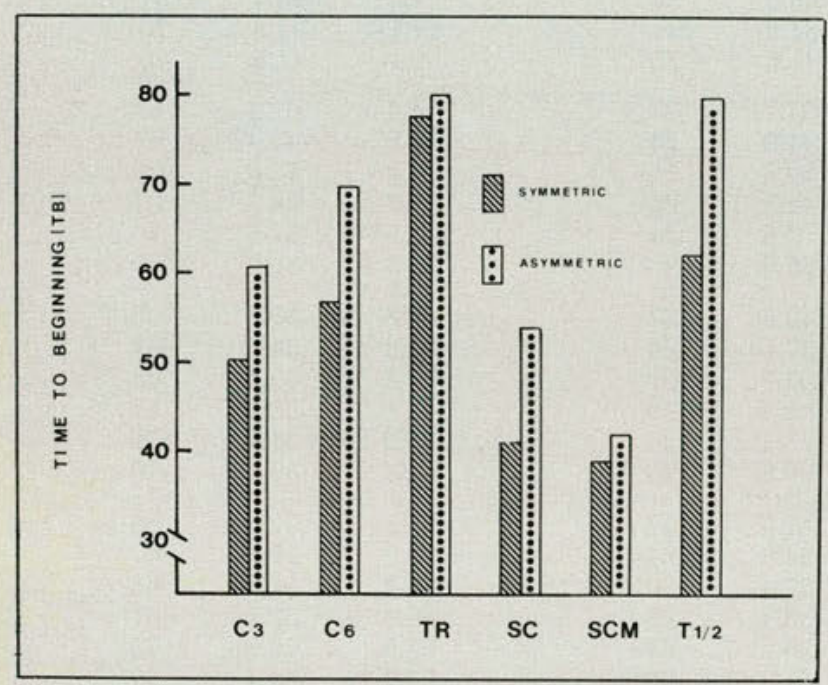

Fig. 2. Main effect for symmetry: time to beginning of motion. Data are expressed as a percentage of total head movement time. metric group, and left-side muscles for the symmetric group reached peak output before left-side muscles for the asymmetric group except for the sternocleidomastoid.

Table 5 summarizes the muscle $\times$ motion interactions. A comparison of the overall mean values for the six head motions showed that peak electrical output was reached earliest by muscles during axial rotations.

Statistical evaluation. The profile analysis was used to determine whether differences existed among subject groups, motions, muscles, and sides of recording for the TP variable. An overall main effect for symmetry was observed ( $p=<.004$ ) (Table 3 ). This indicated that a significant difference occurred between the data describing the profile for the symmetric group and the data for the asymmetric group (Fig. 3).

\section{Total time of muscle activity (TT)}

Descriptive observations. Table 6 presents the muscle $\times$ symmetry $\times$ side data for the dependent variable TT, indicating the total amount of time each muscle was active for the various motions. Five of the six muscles in the symmetric group exceeded their counterparts in the asymmetric group in total time of activity (the sixth muscle, the trapezius, was identical in mean value, 12.4). The values of TT in decreasing order for the symmetric group were: splenius capitis, sternocleidomastoid, C3, C6, upper thoracic level, and trapezius. For the asymmetric group, they were: sternocleidomastoid,

\begin{tabular}{|c|c|c|c|c|}
\hline $\begin{array}{l}\text { Dependent } \\
\text { variable }\end{array}$ & Source of variance & DF & $\mathrm{F}$ & Sig. \\
\hline $\begin{array}{l}\text { Time } \\
\text { to } \\
\text { beginning }\end{array}$ & $\begin{array}{l}\text { Symmetry } \times \text { side } \\
\text { Symmetry } \times \text { motion } \\
\text { (flexion right vs flexion left) } \\
\text { Symmetry } \times \text { motion } \\
\text { (rotation right vs rotation left) } \\
\text { Symmetry }\end{array}$ & $\begin{array}{l}5,537 \\
5,537 \\
5,537 \\
5,537\end{array}$ & $\begin{array}{l}2.51 \\
3.03 \\
2.79 \\
5.77\end{array}$ & $\begin{array}{l}.03 \\
.01 \\
.02 \\
.00003\end{array}$ \\
\hline $\begin{array}{l}\text { Time to } \\
\text { peak }\end{array}$ & Symmetry & 5,536 & 3.54 & .004 \\
\hline $\begin{array}{l}\text { Total } \\
\text { time }\end{array}$ & $\begin{array}{l}\text { Symmetry } \times \text { side } \\
\text { Symmetry } \times \text { motion } \\
(\text { flexion right vs flexion left) } \\
\text { Symmetry } \times \text { motion } \\
(\text { rotation right vs rotation left) } \\
\text { Symmetry }\end{array}$ & $\begin{array}{l}5,537 \\
5,537 \\
5,537 \\
5,537\end{array}$ & $\begin{array}{l}3.17 \\
2.71 \\
3.51 \\
6.89\end{array}$ & $\begin{array}{l}.008 \\
.02 \\
.004 \\
.00001\end{array}$ \\
\hline $\begin{array}{l}\text { Total } \\
\text { activity }\end{array}$ & $\begin{array}{l}\text { Symmetry } \times \text { motion } \\
\text { (flexion right vs flexion left) } \\
\text { Symmetry } \times \text { motion } \\
\text { (rotation vs rotation left) } \\
\text { Symmetry }\end{array}$ & $\begin{array}{l}5,547 \\
\\
5,547 \\
5,547\end{array}$ & $\begin{array}{l}3.30 \\
\\
9.64 \\
3.54\end{array}$ & $\begin{array}{l}.006 \\
.00001 \\
.004\end{array}$ \\
\hline
\end{tabular}




\begin{tabular}{|c|c|c|c|c|c|c|c|c|}
\hline Site & Symmetry & $\overline{\mathrm{X}}$ & S.D. & No. & Side & $\overline{\mathrm{X}}$ & S.D. & No. \\
\hline $\begin{array}{l}\text { Cervical } \\
\text { level } \\
3\end{array}$ & $\begin{array}{l}\text { Symmetric } \\
\text { Asymmetric }\end{array}$ & 61.0 & 39.5 & 160 & $\begin{array}{l}\text { Right } \\
\text { Left } \\
\text { Right } \\
\text { Left } \\
\text { Right side } \bar{X} \\
\text { Left side X }\end{array}$ & $\begin{array}{l}52.1 \\
56.0 \\
55.8 \\
65.2 \\
54.5 \\
63.3\end{array}$ & \begin{tabular}{l|l|}
38.4 & \\
35.6 \\
40.4 \\
38.4 \\
39.7 \\
38.0
\end{tabular} & $\begin{array}{r}103 \\
57 \\
182 \\
222 \\
285 \\
279\end{array}$ \\
\hline $\begin{array}{l}\text { Cervical } \\
\text { level } \\
6\end{array}$ & $\begin{array}{l}\text { Symmetric } \\
\text { Asymmetric }\end{array}$ & 70.7 & 37.8 & 404 & $\begin{array}{l}\text { Right } \\
\text { Left } \\
\text { Right } \\
\text { Left } \\
\text { Right side } \bar{X} \\
\text { Left side X }\end{array}$ & $\begin{array}{l}61.9 \\
56.4 \\
68.4 \\
72.5 \\
66.1 \\
69.2\end{array}$ & $\begin{array}{l}37.1 \\
38.3 \\
38.3 \\
37.4 \\
37.9 \\
38.1\end{array}$ & $\begin{array}{r}103 \\
57 \\
182 \\
222 \\
285 \\
279\end{array}$ \\
\hline $\begin{array}{l}\text { Trapezius } \\
\text { muscle }\end{array}$ & $\begin{array}{l}\text { Symmetric } \\
\text { Asymmetric }\end{array}$ & $\begin{array}{l}77.2 \\
80.8\end{array}$ & $\begin{array}{l}36.3 \\
33.8\end{array}$ & $\begin{array}{l}160 \\
404\end{array}$ & $\begin{array}{l}\text { Right } \\
\text { Left } \\
\text { Right } \\
\text { Left } \\
\text { Right side } \bar{X} \\
\text { Left side X }\end{array}$ & $\begin{array}{l}76.2 \\
79.0 \\
77.2 \\
83.7 \\
76.8 \\
82.8\end{array}$ & $\begin{array}{l}36.8 \\
35.7 \\
35.6 \\
32.0 \\
36.0 \\
32.8\end{array}$ & $\begin{array}{r}103 \\
57 \\
182 \\
222 \\
285 \\
279\end{array}$ \\
\hline $\begin{array}{l}\text { Splenius } \\
\text { capitis } \\
\text { muscle }\end{array}$ & $\begin{array}{l}\text { Symmetric } \\
\text { Asymmetric }\end{array}$ & $\begin{array}{l}49.1 \\
59.4\end{array}$ & $\begin{array}{l}33.4 \\
37.9\end{array}$ & $\begin{array}{l}160 \\
404\end{array}$ & $\begin{array}{l}\text { Right } \\
\text { Left } \\
\text { Right } \\
\text { Left } \\
\text { Right side } \bar{X} \\
\text { Left side X }\end{array}$ & $\begin{array}{l}47.5 \\
52.0 \\
55.1 \\
63.0 \\
52.4 \\
60.7\end{array}$ & $\begin{array}{l}33.4 \\
33.7 \\
38.4 \\
37.1 \\
36.8 \\
36.7 \\
\end{array}$ & $\begin{array}{r}103 \\
57 \\
182 \\
222 \\
285 \\
279\end{array}$ \\
\hline $\begin{array}{l}\text { Sternocleido- } \\
\text { mastoid } \\
\text { muscle }\end{array}$ & Asymmetric & 43.8 & 32.7 & 160 & $\begin{array}{l}\text { Right } \\
\text { Left } \\
\text { Right } \\
\text { Left } \\
\text { Right side } \bar{X} \\
\text { Left side X }\end{array}$ & $\begin{array}{l}41.1 \\
48.7 \\
45.9 \\
48.3 \\
44.2 \\
48.4 \\
\end{array}$ & $\begin{array}{l}33.0 \\
32.0 \\
36.1 \\
36.8 \\
35.0 \\
35.8\end{array}$ & $\begin{array}{r}103 \\
57 \\
182 \\
222 \\
285 \\
279\end{array}$ \\
\hline $\begin{array}{l}\text { Upper } \\
\text { thoracic } \\
\text { level }\end{array}$ & $\begin{array}{l}\text { Symmetric } \\
\text { Asymmetric }\end{array}$ & 79.9 & 40.0 & $\begin{array}{l}160 \\
404\end{array}$ & $\begin{array}{l}\text { Right } \\
\text { Left } \\
\text { Right } \\
\text { Left } \\
\text { Right side } \bar{X} \\
\text { Left side } \bar{X}\end{array}$ & $\begin{array}{l}69.5 \\
54.3 \\
77.6 \\
81.7 \\
74.7 \\
76.1\end{array}$ & $\begin{array}{l}39.7 \\
38.9 \\
35.9 \\
34.4 \\
37.4 \\
37.0\end{array}$ & $\begin{array}{r}103 \\
57 \\
182 \\
222 \\
285 \\
279\end{array}$ \\
\hline
\end{tabular}

splenius capitis, C3, C6, trapezius, and the upper thoracic level. From Table 6 it can be seen that muscles on the right side of the body acted for longer periods of time than did left-side muscles. Also, most of the right-side muscles for the symmetric group acted for longer periods than rightside muscles for the symmetric group, except for trapezius and sternocleidomastoid muscles. Table 6 also indicates that left-side muscles for the symmetric group were active for longer periods than were similar muscles for the asymmetric group, except for the trapezius muscle.

Table 7 summarizes the muscle $\times$ motion interactions. It can be seen that muscle activity lasted longer for axial rotations than any of the other test motions.

Statistical evaluation. A profile analysis was used to examine relationships among subject groups, motions, muscles, and sides of recording for the dependent variable TT. One symmetry $\times$ side interaction, two symmetry $\times$ motion interactions, and one overall main effect for symmetry were significant.

The symmetry $\times$ side interaction was significant ( $p=<.008$ ) (Table 3). This result established that, for individual muscle activity, symmetric subjects differed from their asymmetric counterparts when the side of the body from which the electrical measurements were made is considered. The profiles describing the total amount of muscle action time were influenced by the side of recording, and whether the subjects were symmetric or asymmetric.

In the case of the symmetry $\times$ motion interactions, when TT is considered, significant differences were found between the symmetric and asymmetric groups for lateral flexions and axial 


\begin{tabular}{|c|c|c|c|c|c|c|c|}
\hline \multirow[b]{2}{*}{ Site } & \multirow[b]{2}{*}{ Motion } & \multicolumn{3}{|c|}{ Symmetric } & \multicolumn{3}{|c|}{$\overbrace{}^{\text {Asymmetric }}$} \\
\hline & & $\sqrt{\mathrm{x}}$ & S.D. & No.) & $\sqrt{\bar{x}}$ & S.D. & No.? \\
\hline $\begin{array}{c}\text { Cervical } \\
\text { level } \\
3\end{array}$ & $\begin{array}{l}\text { FF } \\
\text { HYP } \\
\text { FR } \\
\text { FL } \\
\text { RR } \\
\text { RL }\end{array}$ & $\begin{array}{l}52.5 \\
64.4 \\
60.6 \\
71.7 \\
31.1 \\
36.4\end{array}$ & $\begin{array}{l}38.8 \\
43.8 \\
43.5 \\
38.5 \\
10.0 \\
16.4\end{array}$ & $\begin{array}{l}27 \\
24 \\
30 \\
29 \\
24 \\
26\end{array}$ & $\begin{array}{l}49.1 \\
68.9 \\
74.9 \\
80.4 \\
45.5 \\
48.3\end{array}$ & $\begin{array}{l}43.5 \\
41.7 \\
36.2 \\
34.3 \\
31.7 \\
34.9\end{array}$ & $\begin{array}{l}65 \\
67 \\
65 \\
67 \\
70 \\
70\end{array}$ \\
\hline $\begin{array}{c}\text { Cervical } \\
\text { level } \\
6\end{array}$ & $\begin{array}{l}\text { FF } \\
\text { HYP } \\
\text { FR } \\
\text { FL } \\
\text { RR } \\
\text { RL }\end{array}$ & $\begin{array}{l}70.0 \\
78.6 \\
56.8 \\
80.7 \\
29.6 \\
40.8\end{array}$ & $\begin{array}{l}30.5 \\
38.1 \\
44.3 \\
35.2 \\
10.5 \\
25.3\end{array}$ & $\begin{array}{l}27 \\
24 \\
30 \\
29 \\
24 \\
26\end{array}$ & $\begin{array}{l}72.7 \\
89.3 \\
81.4 \\
78.7 \\
50.9 \\
52.9\end{array}$ & $\begin{array}{l}38.9 \\
26.2 \\
34.3 \\
36.4 \\
36.8 \\
36.9\end{array}$ & $\begin{array}{l}65 \\
67 \\
65 \\
67 \\
70 \\
70\end{array}$ \\
\hline $\begin{array}{l}\text { Trapezius } \\
\text { muscle }\end{array}$ & $\begin{array}{l}\text { FF } \\
\text { HYP } \\
\text { FR } \\
\text { FL } \\
\text { RR } \\
\text { RL }\end{array}$ & $\begin{array}{r}96.4 \\
100.0 \\
80.5 \\
86.2 \\
37.3 \\
59.1\end{array}$ & $\begin{array}{r}18.9 \\
0.0 \\
36.1 \\
30.8 \\
34.4 \\
38.4\end{array}$ & $\begin{array}{l}27 \\
24 \\
30 \\
29 \\
24 \\
26\end{array}$ & $\begin{array}{l}97.1 \\
89.0 \\
85.1 \\
92.1 \\
62.1 \\
61.6\end{array}$ & $\begin{array}{l}16.3 \\
28.7 \\
32.0 \\
22.4 \\
38.1 \\
39.6\end{array}$ & $\begin{array}{l}65 \\
67 \\
65 \\
67 \\
70 \\
70\end{array}$ \\
\hline $\begin{array}{l}\text { Splenius } \\
\text { capitis } \\
\text { muscle }\end{array}$ & $\begin{array}{l}\text { FF } \\
\text { HYP } \\
\text { FR } \\
\text { FL } \\
\text { RR } \\
\text { RL }\end{array}$ & $\begin{array}{l}37.9 \\
67.5 \\
48.8 \\
58.4 \\
35.4 \\
46.4\end{array}$ & $\begin{array}{l}28.8 \\
40.2 \\
40.4 \\
38.0 \\
10.2 \\
20.3\end{array}$ & $\begin{array}{l}27 \\
24 \\
30 \\
29 \\
24 \\
26\end{array}$ & $\begin{array}{l}58.1 \\
63.6 \\
65.0 \\
79.0 \\
46.5 \\
45.7\end{array}$ & $\begin{array}{l}43.3 \\
38.3 \\
38.6 \\
34.7 \\
30.9 \\
31.2\end{array}$ & $\begin{array}{l}65 \\
67 \\
65 \\
67 \\
70 \\
70\end{array}$ \\
\hline $\begin{array}{l}\text { Sternocleido- } \\
\text { mastoid } \\
\text { muscle }\end{array}$ & $\begin{array}{l}\text { FF } \\
\text { HYP } \\
\text { FR } \\
\text { FL } \\
\text { RR } \\
\text { RL }\end{array}$ & $\begin{array}{l}66.7 \\
60.9 \\
38.0 \\
30.9 \\
34.4 \\
34.2\end{array}$ & $\begin{array}{l}38.7 \\
34.2 \\
30.5 \\
30.1 \\
24.3 \\
16.5\end{array}$ & $\begin{array}{l}27 \\
24 \\
30 \\
29 \\
24 \\
26\end{array}$ & $\begin{array}{l}61.2 \\
44.2 \\
57.6 \\
39.5 \\
41.1 \\
41.0\end{array}$ & $\begin{array}{l}41.7 \\
33.8 \\
38.8 \\
36.4 \\
28.2 \\
34.1\end{array}$ & $\begin{array}{l}65 \\
67 \\
65 \\
67 \\
70 \\
70\end{array}$ \\
\hline $\begin{array}{l}\text { Upper } \\
\text { thoracic } \\
\text { level }\end{array}$ & $\begin{array}{l}\text { FF } \\
\text { HYP } \\
\text { FR } \\
\text { FL } \\
\text { RR } \\
\text { RL }\end{array}$ & $\begin{array}{l}70.8 \\
79.2 \\
70.1 \\
73.2 \\
40.6 \\
47.7\end{array}$ & $\begin{array}{l}39.3 \\
36.8 \\
40.5 \\
38.6 \\
32.1 \\
39.7\end{array}$ & $\begin{array}{l}27 \\
24 \\
30 \\
29 \\
24 \\
26\end{array}$ & $\begin{array}{l}87.4 \\
96.6 \\
87.8 \\
86.7 \\
67.1 \\
55.8\end{array}$ & $\begin{array}{l}30.4 \\
16.2 \\
29.1 \\
30.4 \\
38.9 \\
42.4\end{array}$ & $\begin{array}{l}65 \\
67 \\
65 \\
67 \\
70 \\
70\end{array}$ \\
\hline
\end{tabular}

rotations only. That is, the overall time of contraction for the muscles was dependent upon the group (symmetry versus asymmetry) and whether they flexed to the right or left $(p=<.02)$, and whether they rotated to the right or left $(p=<.004)$ (Table 3).

Statistical analysis demonstrated a main effect for symmetry ( $p=<.00001)$, indicating a significant difference in profiles between symmetric and asymmetric subjects for the dependent variable TT (Table 3, Fig. 4). This significance was dependent specifically upon the side of the body from which the recordings were made, and upon the motion that was performed (lateral flexion right or left, and rotation right or left).

Total muscle activity (TA)

Descriptive observations. Table 8 presents the muscle $\times$ symmetry $\times$ side data for the dependent variable TA, which describes the relative amount of electrical output for each muscle. The muscles in symmetric subjects exceeded their counterparts in asymmetric subjects in electrical output, except for the trapezius muscle, for which the output of the two subject groups was essentially identical. The values of TA in decreasing order for the symmetric group were: sternocleidomastoid, splenius capitis, C3, C6, upper thoracic, and trapezius; for the asymmetric group they were, first, sternocleidomastoid, then splenius capitis and C3, which were the same, C6, trapezius, and upper thoracic. The muscles on the right side of the body elicited greater overall activity than muscles on the left, except for the sternocleidomastoid. In addition, right-side muscles for symmetric subjects exhibited more electrical activity than right-side muscles of 
asymmetric subjects, with the exception of the trapezius. Left-side muscles for symmetric subjects also exhibited more electrical activity than leftside muscles on asymmetric subjects, again except for the trapezius.

Table 9 summarizes the muscle $\times$ motion interactions. From this table it can be seen that muscle activity was far greater for axial rotations than for any of the other test motions.

Statistical evaluation. The profile analysis of TA indicated that two symmetry $\times$ motion interactions and one overall main effect were significant.

The symmetry $\times$ motion interactions (Table 3 ) indicated that significant differences were observed to be dependent upon the group (symmetric versus asymmetric), direction of flexion (to the right or left) $(p=<.006)$, and direction of rotation (to the right or left) $(p=<.00001)$.

The overall main effect for symmetry ( $p=$ $<.004$ ) was significantly different in symmetric and asymmetric groups (Table 3, Fig. 5). As was the case before when interactions were observed, this main effect for symmetry was dependent upon the motions of right or left lateral flexion and right or left rotation.

\section{Discussion}

The biomechanics literature has been dominated by reports of EMG activity for individual muscular contributions to specific motions. In contrast, this study has looked at the composite contribution of 12 electrode sites that sampled electrical activity during movements of an entire anatomic region. A clinical situation (environment) was used as the basis for the study. The dissection of the electrical signal into four quantitative variables is a novel approach to understanding qualities of timing and relative contributions of muscular activities that are implicit in motion. In addition, the EMG data were synchronized with kinematic data; therefore, very specific statements can be made relative to the muscular activity that paralleled the significant differences in kinematic behavior.

Because of the detailed nature of the myoelectric observations reported in this study, we will summarize briefly first the descriptive findings, to provide a fundamental stage for (1) examining general aspects of muscular performance in the cervical region, and (2) correlating specific aspects of these myoelectric data with kinematic data identified in Part I of this study. Second, because aspects of the data were evaluated statistically, we will discuss the definitive findings in relation to our stated goal, that being a search for correlates between clinical observations of somatic dysfunction

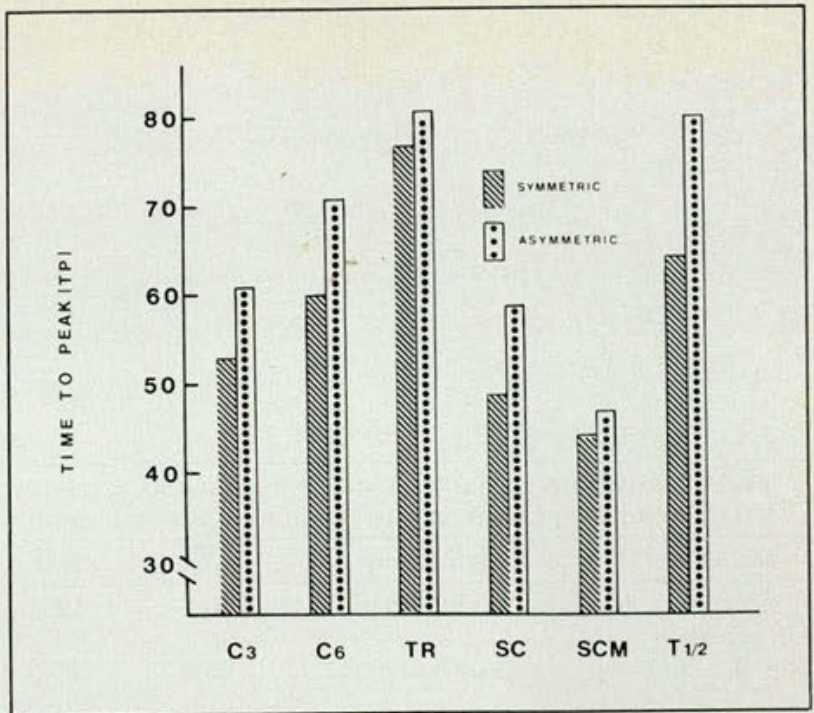

Fig. 3 Main effect for symmetry: time to peak. Values are expressed as a percentage of total head movement time.

and instrumental measures of biomechanical disturbance.

\section{Descriptive observations}

For the symmetric group, myoelectric activity at all sites and for all motions exceeded that of the asymmetric group in both amount and in total time of activity (Table 10). Muscular activity of symmetric subjects also began sooner and peaked sooner. ${ }^{\S}$ This observation agrees with kinematic data ${ }^{1}$ of greater motion range in each and all the movements of the symmetric group versus the asymmetric group.

In general, right-side muscles acted sooner, longer, and stronger than left-side muscles, except for the trapezius and, on one minor occasion, the sternocleidomastoid muscle in regard to TT. The earlier contraction, the added length of contraction, and the added magnitude of the contraction characterizes this sidedness in the symmetric group; that is, in general, right-side muscles in the symmetric group exceeded right-side muscles in the asymmetric group and left-side muscles in symmetric subjects exceeded left-side muscles in asymmetric subjects.

When the electrical activity at all electrode sites for the entire 17 subjects is considered, axial rotations exceeded all other movements in the amount of electrical activity and the time active. In addition, during axial rotations, muscles became active more quickly and their activity peaked more quickly. As in the previous analysis, axial rotation motion ranges $^{1}$ exceeded all others.

For individual muscle performance irrespective

\footnotetext{
${ }^{8}$ The standard for these measurements was each subject's total time of movement.
} 


\begin{tabular}{|c|c|c|c|c|c|c|c|c|}
\hline Site & Symmetry & $\overline{\mathrm{X}}$ & S.D. & No. & Side & $\overline{\mathrm{X}}$ & S.D. & No. \\
\hline $\begin{array}{l}\text { Cervical } \\
\text { level } \\
3\end{array}$ & $\begin{array}{l}\text { Symmetric } \\
\text { Asymmetric }\end{array}$ & 23.6 & $\begin{array}{l}28.1 \\
26.8\end{array}$ & $\begin{array}{l}162 \\
403\end{array}$ & $\begin{array}{l}\text { Right } \\
\text { Left } \\
\text { Right } \\
\text { Left } \\
\text { Right side } \bar{X} \\
\text { Left side } \bar{X}\end{array}$ & $\begin{array}{l}29.3 \\
31.7 \\
24.8 \\
22.6 \\
26.4 \\
24.4\end{array}$ & $\begin{array}{l}27.9 \\
28.5 \\
26.5 \\
27.0 \\
27.1 \\
27.5\end{array}$ & $\begin{array}{r}105 \\
57 \\
180 \\
223 \\
285 \\
280\end{array}$ \\
\hline $\begin{array}{l}\text { Cervical } \\
\text { level } \\
6\end{array}$ & $\begin{array}{l}\text { Symmetric } \\
\text { Asymmetric }\end{array}$ & $\begin{array}{l}25.4 \\
17.5\end{array}$ & $\begin{array}{l}27.1 \\
24.7\end{array}$ & $\begin{array}{r}162 \\
403\end{array}$ & $\begin{array}{l}\text { Right } \\
\text { Left } \\
\text { Right } \\
\text { Left } \\
\text { Right side } \bar{X} \\
\text { Left side } \bar{X}\end{array}$ & $\begin{array}{l}25.3 \\
25.5 \\
19.2 \\
16.2 \\
21.4 \\
18.1\end{array}$ & $\begin{array}{l}27.3 \\
27.0 \\
25.8 \\
23.8 \\
26.5 \\
24.7\end{array}$ & $\begin{array}{r}105 \\
57 \\
180 \\
223 \\
285 \\
280\end{array}$ \\
\hline $\begin{array}{l}\text { Trapezius } \\
\text { muscle }\end{array}$ & $\begin{array}{l}\text { Symmetric } \\
\text { Asymmetric }\end{array}$ & $\begin{array}{l}12.4 \\
12.4\end{array}$ & $\begin{array}{l}21.6 \\
24.4\end{array}$ & $\begin{array}{l}162 \\
403\end{array}$ & $\begin{array}{l}\text { Right } \\
\text { Left } \\
\text { Right } \\
\text { Left } \\
\text { Right side } \bar{X} \\
\text { Left side } \bar{X}\end{array}$ & $\begin{array}{r}14.1 \\
9.2 \\
15.4 \\
10.1 \\
14.9 \\
9.9\end{array}$ & $\begin{array}{r}23.6 \\
17.0 \\
7.4 \\
21.3 \\
26.1 \\
20.5\end{array}$ & $\begin{array}{r}105 \\
57 \\
180 \\
223 \\
285 \\
280\end{array}$ \\
\hline $\begin{array}{l}\text { Splenius } \\
\text { capitis } \\
\text { muscle }\end{array}$ & $\begin{array}{l}\text { Symmetric } \\
\text { Asymmetric }\end{array}$ & $\begin{array}{l}40.3 \\
30.5\end{array}$ & $\begin{array}{l}31.4 \\
31.3\end{array}$ & $\begin{array}{l}162 \\
403\end{array}$ & $\begin{array}{l}\text { Right } \\
\text { Left } \\
\text { Right } \\
\text { Left } \\
\text { Right side } \overline{\mathrm{X}} \\
\text { Left side } \overline{\mathrm{X}}\end{array}$ & $\begin{array}{l}40.7 \\
39.5 \\
33.6 \\
27.9 \\
36.2 \\
30.3\end{array}$ & $\begin{array}{l}31.5 \\
31.5 \\
32.4 \\
30.2 \\
32.2 \\
30.8\end{array}$ & $\begin{array}{r}105 \\
57 \\
180 \\
223 \\
285 \\
280\end{array}$ \\
\hline $\begin{array}{l}\text { Sternocleido- } \\
\text { mastoid } \\
\text { muscle }\end{array}$ & $\begin{array}{l}\text { Symmetric } \\
\text { Asymmetric }\end{array}$ & $\begin{array}{l}35.5 \\
34.5\end{array}$ & $\begin{array}{l}26.2 \\
29.1\end{array}$ & $\begin{array}{l}162 \\
403\end{array}$ & $\begin{array}{l}\text { Right } \\
\text { Left } \\
\text { Right } \\
\text { Left } \\
\text { Right side } \bar{X} \\
\text { Left side } \bar{X}\end{array}$ & $\begin{array}{l}34.5 \\
37.4 \\
35.8 \\
33.5 \\
35.3 \\
34.3\end{array}$ & $\begin{array}{l}25.4 \\
27.7 \\
29.6 \\
28.7 \\
28.1 \\
28.5\end{array}$ & $\begin{array}{r}105 \\
57 \\
180 \\
223 \\
285 \\
280\end{array}$ \\
\hline $\begin{array}{l}\text { Upper } \\
\text { thoracic } \\
\text { level }\end{array}$ & $\begin{array}{l}\text { Symmetric } \\
\text { Asymmetric }\end{array}$ & 10.0 & $\begin{array}{l}24.7 \\
19.0\end{array}$ & $\begin{array}{l}162 \\
403\end{array}$ & $\begin{array}{l}\text { Right } \\
\text { Left } \\
\text { Right } \\
\text { Left } \\
\text { Right side } \bar{X} \\
\text { Left side } \bar{X}\end{array}$ & $\begin{array}{r}15.4 \\
26.7 \\
11.8 \\
8.5 \\
13.1 \\
12.2\end{array}$ & $\begin{array}{l}22.1 \\
27.5 \\
20.9 \\
17.2 \\
21.4 \\
21.0\end{array}$ & $\begin{array}{r}105 \\
57 \\
180 \\
223 \\
285 \\
280\end{array}$ \\
\hline
\end{tabular}




\begin{tabular}{|c|c|c|c|c|c|c|c|}
\hline \multirow[b]{2}{*}{ Site } & \multirow[b]{2}{*}{ Motion } & \multicolumn{3}{|c|}{ Symmetric } & \multicolumn{3}{|c|}{ Asymmetric } \\
\hline & & ( $\bar{x}$ & S.D. & No. ! & $\sqrt{\mathrm{x}}$ & S.D. & No. \\
\hline $\begin{array}{c}\text { Cervical } \\
\text { level } \\
3\end{array}$ & $\begin{array}{l}\text { FF } \\
\text { HYP } \\
\text { FR } \\
\text { FL } \\
\text { RR } \\
\text { RL }\end{array}$ & $\begin{array}{l}22.7 \\
14.7 \\
18.2 \\
16.2 \\
58.5 \\
56.2\end{array}$ & $\begin{array}{l}22.3 \\
24.4 \\
24.5 \\
24.9 \\
11.2 \\
16.7\end{array}$ & $\begin{array}{l}28 \\
25 \\
30 \\
29 \\
24 \\
26\end{array}$ & $\begin{array}{r}18.0 \\
12.0 \\
14.3 \\
9.7 \\
43.5 \\
41.4\end{array}$ & $\begin{array}{l}17.0 \\
18.5 \\
21.9 \\
17.3 \\
27.4 \\
30.8\end{array}$ & $\begin{array}{l}66 \\
65 \\
65 \\
67 \\
70 \\
70\end{array}$ \\
\hline $\begin{array}{c}\text { Cervical } \\
\text { level } \\
6\end{array}$ & $\begin{array}{l}\text { FF } \\
\text { HYP } \\
\text { FR } \\
\text { FL } \\
\text { RR } \\
\text { RL }\end{array}$ & $\begin{array}{r}24.0 \\
7.5 \\
15.1 \\
7.6 \\
53.4 \\
49.8\end{array}$ & $\begin{array}{l}30.8 \\
12.9 \\
17.4 \\
17.5 \\
13.5 \\
22.0\end{array}$ & $\begin{array}{l}28 \\
25 \\
30 \\
29 \\
24 \\
26\end{array}$ & $\begin{array}{r}11.7 \\
3.9 \\
9.2 \\
10.6 \\
33.7 \\
34.0\end{array}$ & $\begin{array}{r}18.7 \\
9.7 \\
17.7 \\
19.0 \\
28.3 \\
29.2\end{array}$ & $\begin{array}{l}66 \\
65 \\
65 \\
67 \\
70 \\
70\end{array}$ \\
\hline $\begin{array}{l}\text { Trapezius } \\
\text { muscle }\end{array}$ & $\begin{array}{l}\text { FF } \\
\text { HYP } \\
\text { FR } \\
\text { FL } \\
\text { RR } \\
\text { RL }\end{array}$ & $\begin{array}{r}0.6 \\
0.0 \\
8.4 \\
8.0 \\
27.6 \\
32.4\end{array}$ & $\begin{array}{r}3.0 \\
0.0 \\
16.6 \\
18.9 \\
18.8 \\
31.0\end{array}$ & $\begin{array}{l}28 \\
25 \\
30 \\
29 \\
24 \\
26\end{array}$ & $\begin{array}{r}0.4 \\
2.6 \\
8.5 \\
5.9 \\
26.7 \\
28.6\end{array}$ & $\begin{array}{r}2.1 \\
8.9 \\
21.1 \\
17.2 \\
28.7 \\
33.2\end{array}$ & $\begin{array}{l}66 \\
65 \\
65 \\
67 \\
70 \\
70\end{array}$ \\
\hline $\begin{array}{l}\text { Splenius } \\
\text { capitis } \\
\text { muscle }\end{array}$ & $\begin{array}{l}\text { FF } \\
\text { HYP } \\
\text { FR } \\
\text { FL } \\
\text { RR } \\
\text { RL }\end{array}$ & $\begin{array}{l}35.1 \\
17.2 \\
32.7 \\
29.3 \\
69.1 \\
62.4\end{array}$ & $\begin{array}{l}26.1 \\
22.2 \\
30.4 \\
30.2 \\
13.3 \\
28.4\end{array}$ & $\begin{array}{l}28 \\
25 \\
30 \\
29 \\
24 \\
26\end{array}$ & $\begin{array}{l}20.2 \\
22.7 \\
22.8 \\
15.0 \\
50.6 \\
49.0\end{array}$ & $\begin{array}{l}25.8 \\
27.0 \\
27.8 \\
27.1 \\
29.8 \\
30.0\end{array}$ & $\begin{array}{l}66 \\
65 \\
65 \\
67 \\
70 \\
70\end{array}$ \\
\hline $\begin{array}{l}\text { Sternocleido- } \\
\text { mastoid } \\
\text { muscle }\end{array}$ & $\begin{array}{l}\text { FF } \\
\text { HYP } \\
\text { FR } \\
\text { FL } \\
\text { RR } \\
\text { RL }\end{array}$ & $\begin{array}{l}18.9 \\
24.8 \\
37.8 \\
29.8 \\
44.5 \\
59.0\end{array}$ & $\begin{array}{l}24.2 \\
24.3 \\
24.6 \\
22.0 \\
22.5 \\
19.3\end{array}$ & $\begin{array}{l}28 \\
25 \\
30 \\
29 \\
24 \\
26\end{array}$ & $\begin{array}{l}15.8 \\
38.6 \\
27.9 \\
33.9 \\
47.5 \\
42.1\end{array}$ & $\begin{array}{l}19.9 \\
30.8 \\
30.4 \\
27.3 \\
25.8 \\
28.6\end{array}$ & $\begin{array}{l}66 \\
65 \\
65 \\
67 \\
70 \\
70\end{array}$ \\
\hline $\begin{array}{l}\text { Upper } \\
\text { thoracic } \\
\text { level }\end{array}$ & $\begin{array}{l}\text { FF } \\
\text { HYP } \\
\text { FR } \\
\text { FL } \\
\text { RR } \\
\text { RL }\end{array}$ & $\begin{array}{r}20.7 \\
7.2 \\
11.2 \\
12.0 \\
38.9 \\
29.4\end{array}$ & $\begin{array}{l}31.2 \\
13.9 \\
16.2 \\
21.2 \\
22.5 \\
25.3\end{array}$ & $\begin{array}{l}28 \\
25 \\
30 \\
29 \\
24 \\
26\end{array}$ & $\begin{array}{r}5.6 \\
1.6 \\
6.5 \\
6.0 \\
17.7 \\
21.1\end{array}$ & $\begin{array}{r}15.2 \\
7.3 \\
16.8 \\
14.4 \\
23.4 \\
23.2\end{array}$ & $\begin{array}{l}66 \\
65 \\
65 \\
67 \\
70 \\
70\end{array}$ \\
\hline
\end{tabular}




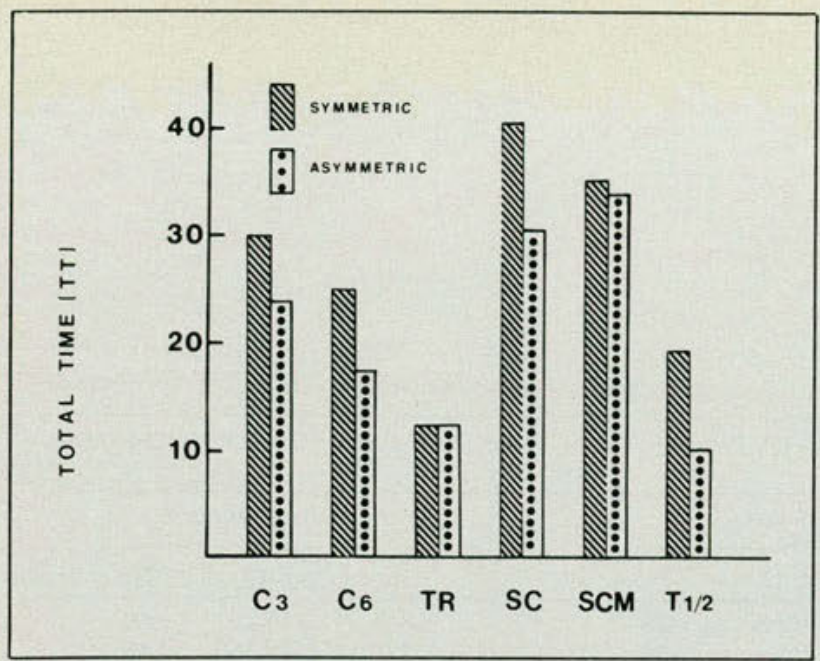

Fig. 4. Main effect for symmetry: total time of activity. Values are expressed as a percentage of total head movement time.

of group (symmetry), the sequence of activity for the six muscles was revealing. If we look at the two muscles whose activities were earliest, longest, and strongest, they were the sternocleidomastoid, a major axial rotator, and the splenius capitis, which was active in the upper cervical region where a majority of cervical spine displacement took place during movement. The intermediate location of the two electrodes sites at C3 and C6 probably influenced the fact that the degree of electrical activity at these sites was more moderate. The trapezius and upper thoracic paravertebral sites were the least active, as might be predicted because of their more peripheral anatomic location.

\section{Statistical findings}

We chose to examine four different aspects of the electrical signal. The first two expressed elements of relative speed, the third how long the muscles were active, and the fourth how much total relative electrical activity was produced. Data from the measurements of each of these qualities were significant in distinguishing the symmetric group from the asymmetric group. An internal relationship is readily predictable between findings of (1) the previously reported decrement in motion range for the asymmetric subjects, ${ }^{1}$ and (2) a generalized reduction in electrical activity for the same group. These two factors, motion range and electrical activity, appear to be objective indicators and intimate functional components; they represent complementary aspects of a movement system. Importantly, the instrumental findings in the experimental group paralleled the fact that assignment of subjects to this group was based on the presence of a clinical sign of cervical dysfunction.
The main effect between the two groups can be described even more specifically for three of these four variables (TB, TT, and TA) (Table 10). Significant differences existed when relations between motion directions to the right and to the left were examined, both for sidebending and for axial rotation, that is, the way symmetric subjects moved to the right in relation to left was different from the way asymmetric subjects performed. (Throughout the statistical design, there were no significant differences beween groups for the forward and backward flexion contrast.) Additionally, for two of the measurements, TB and TT, the main effect for symmetry existed specifically in the relationships between sides of recording, right side/left side. That is, when symmetric subjects moved in a given direction, the speeds of contraction of right muscles in relation to left muscles were significantly different from those of the asymmetric subjects.

These details about sensitivity to directions of motion and to side imply a difference in the reflex control of motion in the asymmetric subjects. One purpose of reflex control is to effect a coordination of response from antagonistic muscles, which act together to provide an equally smooth operation in opposing directions of movement. Clinical tests for motion asymmetry examine for signs of disturbance in the efficiency of this control function to provide objective findings for analysis of musculoskeletal dysfunction.

Apart from asymmetric response to movement, what other clinical signs of spinal movement dysfunction have been previously investigated? Some of the earliest signs of problems in musculoskeletal tissue were reviewed by Denslow, ${ }^{6}$ Denslow and coworkers, ${ }^{7}$ and Korr ${ }^{8}$ during their investigations of a neural basis for lesioned spinal segments. The clinical signs included palpable findings of hyperesthesia, hyperirritability (shown by altered muscular activity and altered states of muscle contraction), changes in tissue texture, and changes in local circulation. They reported the presence of lowered reflex thresholds at key spinal segments that had palpable findings of altered function. Cole $\mathrm{e}^{9-15}$ conducted a series of experiments involving animals in which local somatic dysfunction had been experimentally induced, and Denslow and Clough, ${ }^{16}$ and Denslow and Hassett ${ }^{17}$ supported these clinical findings. Low reflex thresholds and disturbed motor performance were associated with hyperesthesia, abnormal tissue texture, and a hyperemic or congested microenvironment.

Travell and Simons ${ }^{18}$ studied human tissue biopsies from local, clinically defined problem areas, which were termed trigger points. In these pe- 
ripheral sites of neuromuscular dysfunction, they called particular attention to the sensory and/or motor hyperirritability that was present. These authors described the regulatory mechanisms in these areas as being faced with a contradictory situation: While the hyperactivity caused increased metabolic demands, disturbance of the autonomic aspects of the spinal circuit caused a decrease in circulation. The outcome was a compromise of the internal environment, with an accompanying alteration of normal motor function.

\section{Comment}

A major outcome of these studies of somatic tissue alteration was the implication of disturbance to the motor control system. It is appropriate, therefore, to consider our experimental results in relation to these regulatory controls.

The peripheral control system is dependent upon

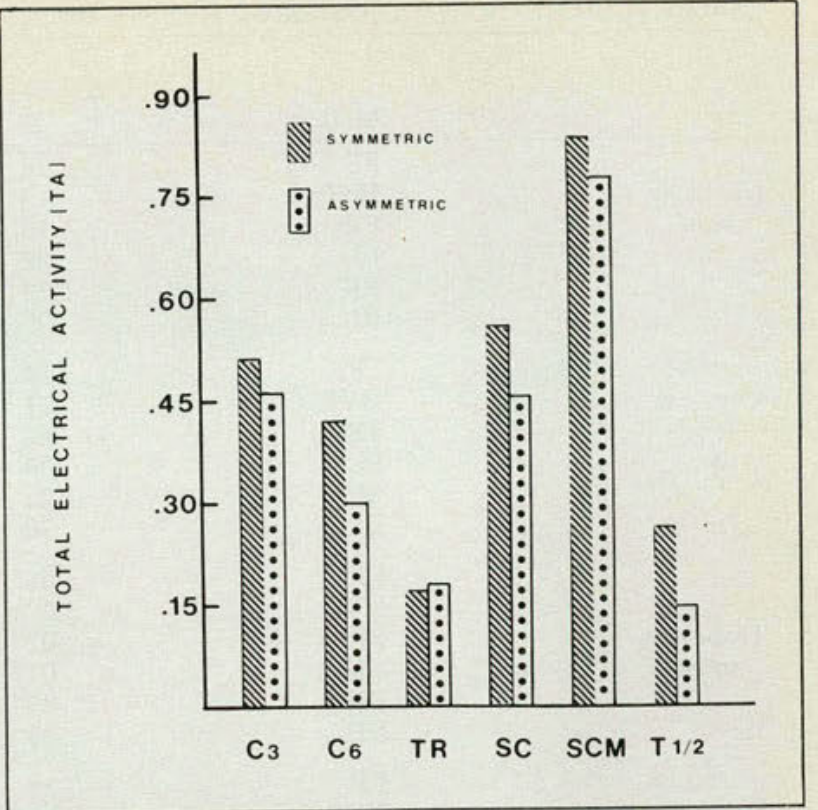

Fig. 5. Main effect for symmetry: total electrical activity. Data are expressed in EMG units.

\begin{tabular}{|c|c|c|c|c|c|c|c|c|}
\hline Site & Symmetry & $\overline{\mathrm{X}}$ & S.D. & No. & Side & $\overline{\mathrm{X}}$ & S.D. & No. \\
\hline $\begin{array}{c}\text { Cervical } \\
\text { level } \\
3\end{array}$ & Asymmetric & .46 & .84 & 166 & $\begin{array}{l}\text { Right } \\
\text { Left } \\
\text { Right } \\
\text { Left } \\
\text { Right side } \bar{X} \\
\text { Left side } \bar{X}\end{array}$ & $\begin{array}{l}.54 \\
.45 \\
.51 \\
.41 \\
.53 \\
.42\end{array}$ & $\begin{array}{l}.91 \\
.72 \\
.85 \\
.71 \\
.87 \\
.70\end{array}$ & $\begin{array}{r}109 \\
57 \\
185 \\
224 \\
294 \\
281\end{array}$ \\
\hline $\begin{array}{c}\text { Cervical } \\
\text { level } \\
6\end{array}$ & $\begin{array}{l}\text { Symmetric } \\
\text { Asymmetric }\end{array}$ & .30 & .67 & 409 & $\begin{array}{l}\text { Right } \\
\text { Left } \\
\text { Right } \\
\text { Left } \\
\text { Right side } \bar{X} \\
\text { Left side } \bar{X}\end{array}$ & $\begin{array}{l}.44 \\
.38 \\
.34 \\
.26 \\
.38 \\
.29\end{array}$ & $\begin{array}{l}.71 \\
.58 \\
.61 \\
.48 \\
.65 \\
.50\end{array}$ & $\begin{array}{r}109 \\
57 \\
185 \\
224 \\
294 \\
281\end{array}$ \\
\hline $\begin{array}{l}\text { Trapezius } \\
\text { muscle }\end{array}$ & $\begin{array}{l}\text { Symmetric } \\
\text { Asymmetric }\end{array}$ & .18 & $\begin{array}{l}.37 \\
.43\end{array}$ & $\begin{array}{l}166 \\
409\end{array}$ & $\begin{array}{l}\text { Right } \\
\text { Left } \\
\text { Right } \\
\text { Left } \\
\text { Right side } \bar{X} \\
\text { Left side } \bar{X}\end{array}$ & $\begin{array}{l}.20 \\
.13 \\
.22 \\
.15 \\
.21 \\
.14\end{array}$ & $\begin{array}{l}.38 \\
.33 \\
.46 \\
.40 \\
.43 \\
.38\end{array}$ & $\begin{array}{r}109 \\
57 \\
185 \\
224 \\
294 \\
281\end{array}$ \\
\hline $\begin{array}{l}\text { Splenius } \\
\text { capitis } \\
\text { muscle }\end{array}$ & $\begin{array}{l}\text { Symmetric } \\
\text { Asymmetric }\end{array}$ & .46 & $\begin{array}{l}.65 \\
.70\end{array}$ & $\begin{array}{l}166 \\
409\end{array}$ & $\begin{array}{l}\text { Right } \\
\text { Left } \\
\text { Right } \\
\text { Left } \\
\text { Right side } \bar{X} \\
\text { Left side X }\end{array}$ & $\begin{array}{l}.57 \\
.52 \\
.49 \\
.44 \\
.52 \\
.46\end{array}$ & $\begin{array}{l}.66 \\
.64 \\
.70 \\
.69 \\
.69 \\
.68\end{array}$ & $\begin{array}{r}109 \\
57 \\
185 \\
224 \\
294 \\
281\end{array}$ \\
\hline $\begin{array}{l}\text { Sternocleido- } \\
\text { mastoid } \\
\text { muscle }\end{array}$ & Asymmetric & .82 & 1.00 & 166 & $\begin{array}{l}\text { Right } \\
\text { Left } \\
\text { Right } \\
\text { Left } \\
\text { Right side } \bar{X} \\
\text { Left side X }\end{array}$ & $\begin{array}{l}.78 \\
.90 \\
.75 \\
.80 \\
.76 \\
.82\end{array}$ & $\begin{array}{r}.99 \\
1.03 \\
.93 \\
1.03 \\
.95 \\
1.03\end{array}$ & $\begin{array}{r}109 \\
57 \\
185 \\
224 \\
294 \\
281\end{array}$ \\
\hline $\begin{array}{c}\text { Upper } \\
\text { thoracic } \\
\text { level }\end{array}$ & Asymmetric & .15 & .39 & 166 & $\begin{array}{l}\text { Right } \\
\text { Left } \\
\text { Right } \\
\text { Left } \\
\text { Right side } \bar{X} \\
\text { Left side } \bar{X}\end{array}$ & $\begin{array}{l}.24 \\
.28 \\
.17 \\
.12 \\
.20 \\
.16\end{array}$ & $\begin{array}{l}.42 \\
.34 \\
.33 \\
.29 \\
.37 \\
.31\end{array}$ & $\begin{array}{r}109 \\
57 \\
185 \\
224 \\
294 \\
281\end{array}$ \\
\hline
\end{tabular}




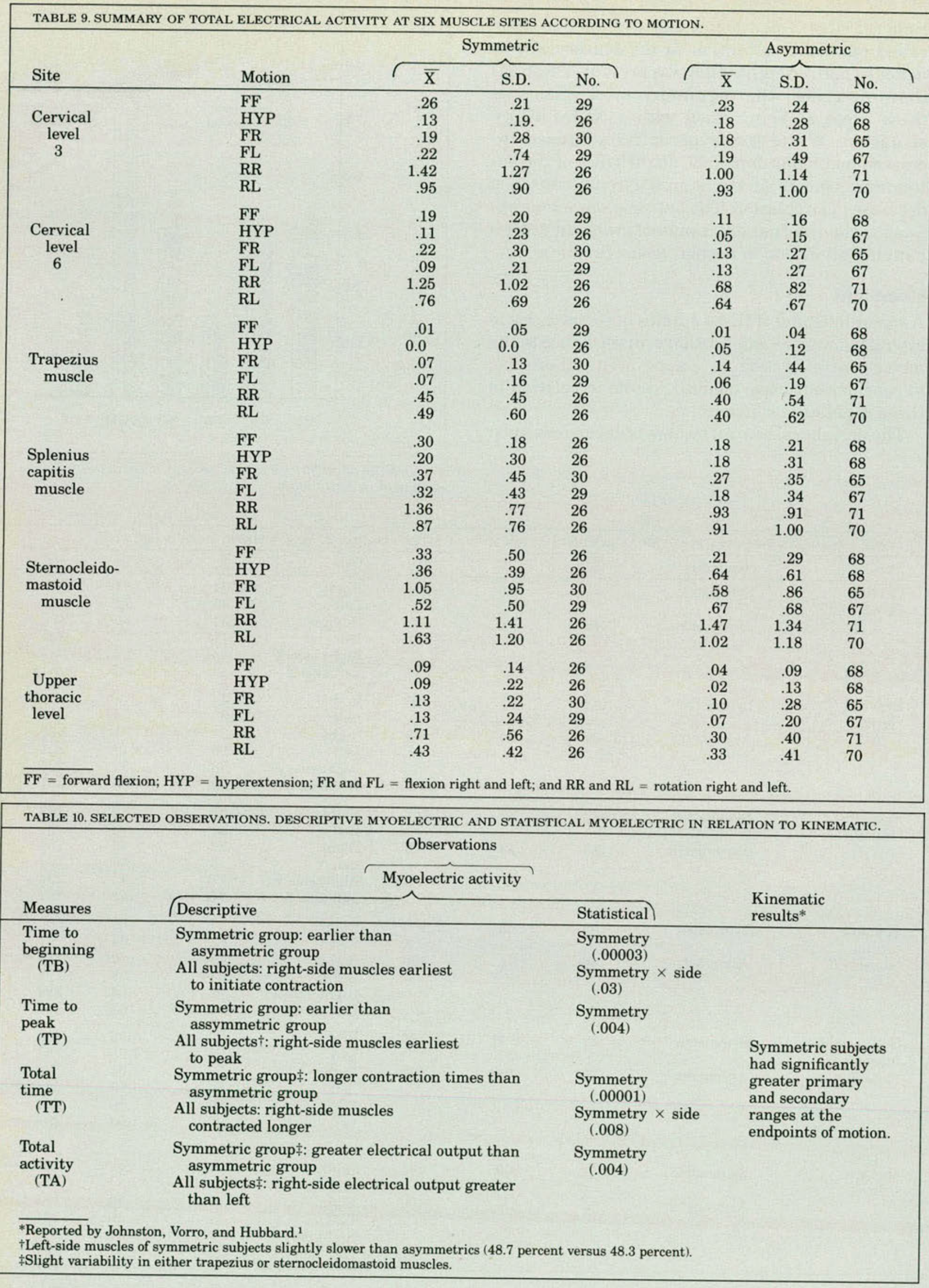


proper functioning of factors such as the mechanical properties of muscle, muscle load, force feedback from tendons, and modulation of activity via length and velocity feedback from spindle receptors. Additionally, it is the continuous flow of information from these controllers that permits this regulatory system to be "equivalent" and capable of functional symmetry. ${ }^{19}$

In an unhealthy or compromised microenvironment, it follows that the regulatory reflex pathways for control of movement will be altered in some way. That is, either the information gathered at the periphery may be in error, or the constant flow of information may be interrupted.

When the sensitivity of this control system is recognized, there is expectation of signs of altered reflex function when symmetry no longer prevails. In our experimental group, the findings of significantly different myoelectric behavior (coupled with the differences in kinematic performance of the entire head and neck region) imply an altered reflex control of our test movements. We consider that our instrumental measurements (detailing differences between symmetric and asymmetric subject groups) reinforce the clinical findings of dysfunction, which are expressed as asymmetric responses of the musculoskeletal tissues during motion tests. They support the concept of somatic dysfunction as a disturbance of the internal environment that is intimately associated with disturbed reflex control of the human peripheral movement system.

1. Johnston, W., Vorro, J., and Hubbard, R.P.: Clinical/biomechanic correlates for cervical function. Part I. A kinematic study. JAOA 85:429-37, Jul 85

2. Hobart, D., et al.: Electronic timer for synchronized electromyography and cinematography. Am J Phys Med 52:243-9. Oct 73

3. Bechtold, J., et al.: Head orientation measured with a video system. $J$ Biomech Eng 105:404-6, Nov 83
4. Basmajian, J.F.: Muscles alive. Their functions revealed by electromyography. Ed. 4. Williams \& Wilkins Co., Baltimore, 1979

5. Morrison, D.F.: Multivariate statistical methods. Ed. 1. McGraw-Hill Book Co., New York, 1967

6. Denslow, J.S.: An analysis of the variability of spinal reflex thresholds. J Neurophysiology 7:207-15, Jul 44

7. Denslow, J.S., Korr, I.M., and Krems, A.D.: Quantitative studies of chronic facilitation in human motoneuron pools. Am J Physiol 150:229-38, Aug 47

8. Korr, I.M.: The neural basis of the osteopathic lesion. JAOA 47:191-8, Dec 47

9. Cole, W.V.: The effects of the atlas lesion. A preliminary report. JAOA 47:150-2, Nov 47

10. Cole, W.V.: The osteopathic lesion complex. II. The effects of the atlas lesion after ninety-six hours and after six weeks. JAOA 48:7-9, Sep 48 11. Cole, W.V.: The osteopathic lesion complex. V. The effects of the seventh cervical vertebral lesion after ninety-six hours, six weeks, and six months. JAOA 48:281-8, Feb 49

12. Cole, W.V.: The osteopathic lesion complex. VI. The effects of the osteopathic lesion on the central nervous system. JAOA 48:394-8, Apr 49 13. Cole, W.V.: The osteopathic lesion complex. VII. The effects of the experimental osteopathic lesion, chemical irritants in the muscle at the level of the sixth thoracic segment, and chemical irritants in the liver. JAOA 49:135-41, Nov 49

14. Cole, W.V.: The osteopathic lesion syndrome. VIII. The effects of an experimental vertebral lesion on the gross structure of the atlanto-occipital region. JAOA 49:447-50, May 50

15. Cole, W.V.: The osteopathic lesion syndrome. IX. Some effects of the osteopathic vertebral lesion in striated musculature and associated structures. JAOA 49:513-22, Jun 50

16. Denslow, J.S., and Clough, G.H.: Electromyographic studies of structural abnormalities. JAOA 41:175-9, Dec 41

17. Denslow, J.S., and Hassett, C.C.: Spontaneous and induced spasm in structural abnormalities. JAOA 42:207-11, Jan 43

18. Travell, J.G., and Simons, D.G.: Myofascial pain and dysfunction. The trigger point manual. William \& Wilkins Co., Baltimore, 1983

19. Houk, J., and Henneman, E.: Feedback control of skeletal muscles. Brain Res 5:433-51, Aug 67

This work was supported by AOA grant no. 79-05-79.

Accepted for publication in October 1986. Updating, as necessary, has been done by the authors.

Dr. Vorro is an associate professor in the Department of Anatomy at Michigan State University, College of Osteopathic Medicine, East Lansing, Michigan, and Dr. Johnston is professor, Department of Family Medicine, MSUCOM.

Dr. Vorro, Michigan State University, College of Osteopathic Medicine, Department of Anatomy, East Fee Hall, East Lansing, Michigan 48824. 


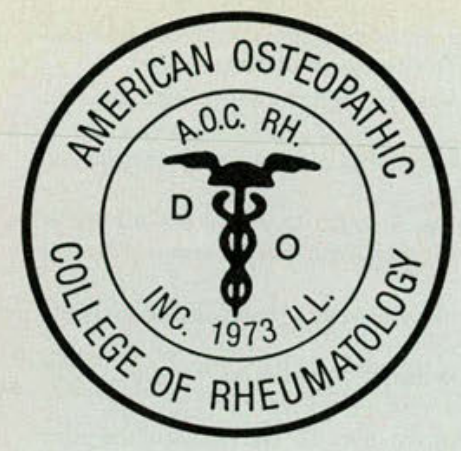

Robert Speer, D.O.

President

Donald Phillips, D.O.

Executive Secretary

\section{AMERICAN OSTEOPATHIC COLLEGE OF RHEUMATOLOGY}

in cooperation with

\section{RIKER LABORATORIES INC.}

OFFERS A FELLOWSHIP PUBLICATION AWARD PROGRAM

The American Osteopathic College of Rheumatology in cooperation with Riker Laboratories, Inc. is excited to announce the establishment of the first annual Osteopathic Fellow Rheumatology Publication Award. This was established to support creative scientific and clinical publications by Osteopathic Fellows in Rheumatology, Family Practice, Allergy and Immunology and Internal Medicine, as well as to acknuwledge the importance of the Osteopathic profession in Rheumatology.

The topic for the first original paper is "The Uses of NSAID's". Judging will be done by members of the American College of Osteopathic Rheumatology. The winner will have his/her article published in an Osteopathic journal, and be invited to present the paper to the American Osteopathic College of Rheumatology at the next annual American Osteopathic Association convention. Expenses for the trip, and an honorarium will be provided by Riker

Laboratories, Inc.

Deadline for submission of the paper is August 31, 1987.

Papers received after this date will be applied to next years competition.

Questions concerning the award, and those interested in applying for this competitive publication award should send the article to:

Gerald Teplitz, D.O., F.A.O.C.Rh.

Chairman, Educational Council

The American Osteopathic College of Rheumatology

5402 Flat lands Avenue

Brooklyn, New York 11234 